\title{
Determinants of Income Diversification among Rural Households in the Mekong River Delta: The Economic Transition Period
}

\author{
Long Hau LE ${ }^{1}$, Tan Nghiem LE
}

Received: February 22, 2020 Revised: March 08, 2020 Accepted: April 03, 2020

\begin{abstract}
This paper examines the factors that drive temporal income diversification in rural areas of the Mekong River Delta in Vietnam, based on a framework that conceptualized diversification as a function of a household's capacity to diversify and incentives (both push and pull factors) to diversify. Drawing from five rounds of the Vietnam Living Standard Measurement Surveys covering a 13-year span (1993-2006), two panel datasets made from five cross-sectional samples are used for the analyses. The data are drawn from the Vietnam General Statistics Office. Both tobit model and Ordinary Least Squares model with random and fixed effects are applied. The main points emerging from the analysis is that income diversification is strongly influenced by household labor capacity. The relationship between household labor capacity and increasing insertion in non-farming wage activities is not driven by unobserved time-invariant factors such as household ability and motivation, but is instead driven by the higher labor capacity of households. In terms of the other household capacity variables, the effect of farm size is much larger in terms of retaining households in traditional occupations as compared to pushing them towards non-farm wage employment. Other variables such as household access to financial capital do not play an important role.
\end{abstract}

Keywords : Vietnam, Mekong River Delta, income diversification, time-allocation, household

JEL Classification Code: D13, J22, J24, O15, R20 (I20)

\section{Introduction}

Income is one of important indicator for evaluating human capital (e.g., Chulanova \& Ussenova, 2015) and many economic theories (e.g., Ramcharran, 2017). Over the economic transition period in Vietnam, rural households are less likely to spend time and earn their income from farm self-employment and are more likely to rely on non-farm wage employment activities. This paper seeks to identify the determinants of both cross-sectional and temporal income

\footnotetext{
${ }^{1}$ First Author and Corresponding Author. College of Economics, Can Tho University, Vietnam [Postal Address: Campus II, 3/2 Street, Xuan Khanh Ward, Ninh Kieu District, Can Tho City, 900000, Vietnam] Email: Ilhau@ctu.edu.vn

2 Doctor, College of Economics, Can Tho University, Vietnam. Email: tannghiem@ctu.edu.vn

(c) Copyright: The Author(s)

This is an Open Access article distributed under the terms of the Creative Commons Attribution Non-Commercial License (http://Creativecommons.org/licenses/by-nc/4.0/) which permits unrestricted noncommercial use, distribution, and reproduction in any medium, provided the original work is properly cited.
}

diversification among rural households in the Mekong River Delta (MRD) during the course of economic transition in Vietnam.

The existing literature on income diversification in Vietnam provides a countrywide picture and is based on information gathered in the 1990s. For example, van de Walle and Cratty (2004) focus on the determinants of offfarm self-employment in rural Vietnam over the period 1993 and 1998, while Minot, Epprecht, Anh, and Trung (2006) rely on cross-section data sets gathered in 1993, 1998, and 2002. In contrast, this paper uses data that cover a much longer period (1993 to 2006) and exploits the panel element of the data to examine factors that drive diversification.

Given the specific context of the MRD wherein farm self-employment is the traditional and primary income source while non-farm wage employment is a non-traditional source as well as the increasing movement into the latter, this paper's analysis focuses on these two sources of income.

The rest of this paper is organized as follows. Section 2 provides a conceptual framework. Detailed information about the data used is in Section 3. Model specification 
is outlined in Section 4. Sections 5 are for discussions on determinants of temporal income diversification. Section 6 contains concluding remarks.

\section{Conceptual Framework}

The literature tends to define income diversification in terms of increasing participation of rural (farm) households in non-farming activities. Theoretically, the time-allocation of rural households to different activities draws on Chayanov's theory of the agricultural household as a producer and a consumer.

The common strength of these farm household models, especially the Barnum-Squire model (1979), is "to provide a framework for generating predictions about the responses of the farm household to changes in domestic (household size and structure) and market (output prices, input prices, wage rates, and technology) variables" (Ellis, 1993, p.131). For income diversification, the household model conceptualizes time-allocation to different activities as a function of the relative returns to labor time from non-farm versus on-farm income generating options. That is, given its endowments - land, labor and other production factors - the household will make decisions on whether more labor time should be allocated to farm production or shifted to non-farm wage or other self-employment activities by comparing the marginal return between these opportunities. On this basis, these models argue that factors that lead to higher on-farm returns, for example, increases in farm output price or in farm productivity, would tend to reduce the motivation to diversify. In contrast, (exogenous) changes that provide higher earnings opportunities from non-farm self-employment or an increase in off-farm/non-farm wage rates are more likely to motivate a movement away from farm income sources (Ellis, 2000).

While the agricultural household model sketched above with its focus on the role of relative prices and incentives in determining diversification is a useful starting point, it has been criticized. Ellis (2000, p.57) argues that the farm household model is not "always very good at capturing inter-temporal dimensions of livelihoods strategies, or at describing the circumstances of survival under stress." Departing from a formal model, he goes on to motivate diversification in terms of "demand-pull diversification" (for wealth accumulation objectives) versus "push-distress diversification" (to manage risk, cope with shock or to escape from declining farm income). The former strategy is mainly driven by "pull factors," while the latter is, conversely, motivated by "push factors" (see Barrett, Reardon, \& Webb, 2001; Davis \& Bezemer, 2003; Ellis, 2000; Haggblade, Hazell, \& Reardon, 2002; Start, 2001).

Reardon, Berdegué, Barrett, and Stamoulis (2007) argue that the literature on determinants of income diversification, which characterizes it in terms of pull and push factors, also gives undue importance to the incentives underlying diversification and does not pay enough attention to household capacity variables. In Reardon's approach, the household capacity variables, defined as capital assets, play a central role in determining the extent of diversification. According to this approach, the extent of participation in a certain activity (diversification strategy) is modeled as a function of variables capturing household available capacity and incentives to undertake that activity (diversification strategy). The household in this case is assumed to maximize earnings subject to constraints imposed by its limited resources and a desire to minimize risk (Reardon et al., 2007).

In this framework, there are two groups of variables that determine diversification - a set of variables falling under the category of household capacity and another in the category "incentives to diversify." All variables under these two groups can be at both the meso-level and micro-level. The "incentives to diversify" group may be further divided into variables such as relative prices of inputs and outputs associated with farm and non-farm activities and variables, which reflect the relative risk associated with farm and nonfarm activity. In fact, these two sets of "incentives" variables are similar to the two familiar and widely used terms: the "pull factors" and "push factors."

In terms of the "pull factors," many empirical studies (see, for example the comprehensive review by Reardon, 1997 or Ellis, 1998), have supported the influence of relative earnings opportunities across farm and non-farm work in driving and supporting diversification. Income gained from non-farm activities speeds up capital accumulation, which in turn facilitates larger investments in agriculture, in the existing non-farm enterprise or provides the initial financial requirements for setting up a new activity. Reardon et al. (2007) point out the dynamic interactive process between earning options, sectors and income strategies (Reardon et al., 2007).

The "push factors" driving households towards nonfarm activities may be triggered by circumstances with which a specific household, a group of households or even all households within the region are confronted. The push factors include both those that push households to undertake non-farm options as either "risk management strategies" (ex ante diversification) or "risk coping strategies" (ex post diversification) for the sake of income smoothing (Reardon et al., 2007). These relate to what is noted by Alderman, Paxson and DEC (1992) as "the fundamental bifurcation of strategies to deal with risk and cope with shocks" and are discussed in the literature (see Barrett et al., 2001; Davis \& Bezemer, 2003; Ellis, 2000; Haggblade et al., 2002; Start, 2001). More specifically, the "push" factors leading rural households to diversify into non-farm employment are large variations in farm income which may be driven by weather 
conditions, rainfall fluctuations, drops in land productivity, and/or changes in policy and weaknesses in rural factor (credit, insurance) markets (Reardon et al., 2007).

The household capacity variables refer to various types of assets that enable households to engage in non-farm activities and include all forms of capital broadly defined as - human, physical, financial, and social capital. Under Reardon et al.'s (2007) framework as well as in the literature in general, capital implies not just private assets but also household accessibility to public assets. In other words, the category of capacity variables proposed as determinants of income diversification may be measured at different levels: micro-level (household- and/or individual-level) and mesolevel (regional- or village-level).

At the meso-level, the infrastructure (communication, roads, transport) faced by a household/village is considered an important factor driving diversification. Better access to institutional and physical infrastructure may be expected to lower the cost of acquiring information, lower transport and transaction costs, and may enhance the potential returns from and the probability of involvement in non-farm activity (Barrett \& Reardon, 2000; Ellis, 2000; Lanjouw \& Feder, 2001; Reardon et al., 2007). At the same time, improvements in road and information accessibility may lead to higher agricultural incomes and may make farming more attractive and reduce movement towards non-farm activity (Reardon et al., 2007). Previous empirical studies tend to use proximity to towns, access to roads, electricity and water to examine the effect of public infrastructure system on non-farm employment (see Barrett et al., 2001; Ellis, 1998; Reardon et al., 2007). Alternative approaches use dummy variables indicating the residence of households (commune or region) to capture differences in capital. Examples of this approach are the studies by van de Walle and Cratty (2004) and Minot et al. (2006) for Vietnam.

Social capital is the second capacity variable and is typically measured at the meso and the micro-level (Reardon et al., 2007). Social capital is defined by Ellis (2000, p.36) as "reciprocity within communities and between households based on trust deriving from social ties". For a clearer vision of its role, social capital at the individual level is defined as "the degree of interaction with others in the context of social networks, can enable economic agents to reduce transaction costs and partially address access constraints arising from imperfect markets" (Davis, 2004, p.7). Social networks are extended to personal and family networks, formal and informal organizations. Social capital is clearly difficult to describe in other than broad qualitative terms (Ellis, 2000). Very few studies have, thus, attempted to measure quantitatively the impact of social capital on household income level and diversification (Davis, 2004; Reardon et al., 2007). Instead, qualitative variables or proxies, such as membership in organizations and "connections," are used to identify the impact of social capital on diversification (Reardon et al., 2007).

The third, crucial, set of capacity variables refers to private goods at the micro-level, including human, physical and financial capital mainly possessed or accessed by the household. Human resources include the quality of labor (education, experience, health) available to the household (Carney, Drinkwater, Rusinow, Neefjes, Wanmali, \& Singh, 1999; Ellis, 2000) and the quantity (Reardon et al., 2007). Both the quality and quantity of labor are necessary to meet the minimum requirements of any production process and hence will play a role in determining income diversification. As a key source of human capital, education has received a lot of attention as it is the most likely means through which individuals and households can access high return nonfarm earning options (Senadjki, Mohd, Bahari, \& Hamad, 2017). Findings from empirical studies in Nicaragua (Corral \& Reardon, 2001), India (Lanjouw \& Shariff, 2002) and Bangladesh (Hossain, 2004) all show that less educated households (head) remain in low paid farm wage employment or are engaged in very low productivity non-farm options, while more educated households tend to earn more from non-farm skilled activities (Abdulai \& Delgado, 1999).

A number of authors (Reardon, 1997; Ellis, 1998) have examined the effect of the quantity of labor on non-farm participation. Typically, rural households with more workers tend to have a higher probability of engaging in non-farm activities. Households with a larger number of household members experience land scarcity and are unable to fully absorb household labor in traditional employment resulting in low or zero returns to a marginal worker. This provides the impetus to seek and participate in non-farm activities, which may provide a higher return as compared to the low or zero level of return if they would remain in farm production. To examine the effects of household labor quantity on diversification, variables such as total number of workers in a household the proportion of workers to the size of household, and household size are often used in empirical studies.

In terms of physical capital at the household level, landholding of rural households is a widely used measure. Landholdings may play an important role in diversification. First, the size of a household's landholdings is likely to be highly correlated with farm income and also provides access to credit. Larger landholdings may allow a household to pursue non-farm activities through earnings generated from the farm, through sale of land or through greater access to credit. At the same time, households with smaller landholdings and the landless may be pushed into non-farm activities due to limited access to land. Second, owning land may be a necessary requirement for joining some organizations, for example farmers' union, which increases social capital and, in turn, opens more options for households to diversify away farm income source. Accordingly, landholdings are most likely to 
be an important determinant of diversification into non-farm activities, but, its effect on diversification may be non-linear. Larger landholdings may offer access to capital and allow a household to generate resources to move away from farming but at the same time larger landholdings may also make farming a more attractive option. The empirical literature supports this idea as a larger amount of landholding increases the household capacity to diversify into non-cropping income sources (cotton, livestock and non-farm activities) in Southern Mali (see Abdulai \& CroleRees, 2001) while it reduces the share of non-farm income in Vietnam (see Minot et al., 2006).

The final capacity variable refers to financial capital. This capital is conceptualized as stocks of money, mainly savings and borrowings, to which the household has access (Ellis, 2000). However, missing or poorly functioning formal financial markets as are likely to occur in rural developing countries, for example in sub-Saharan Africa, makes it more likely that household savings are stored in other forms, such as livestock and gold. For this reason, the value of livestock at hand or/and access to credit have been used as proxies to examine the role of financial capital as a potential determinant of income diversification (see Escobal, 2001). Empirically, the effects of financial capital differ depending on the type of proxy used to capture this type of capital and across types of diversification. For example, using data from Peru, Escobal (2001) finds that higher values of livestock lower the level of income attributable to non-farm selfemployment and non-farm wage employment while having access to credit supports movement towards self-employed activities but does not significantly change the income share from non-farm wage employment.

To conclude, this section has briefly reviewed the theoretical and empirical literature on determinants of income diversification into non-farm activity among rural households in developing countries. The empirical work that follows draws on this discussion and especially the classification of the determinants of diversification into household capacity variables and variables that influence the incentives to diversify to specify econometric models and subsequently to interpret the estimates.

\section{Data}

The data used for the analyses in this paper are drawn from five rounds of the Living Standards Measurement Surveys (LSMS) in Vietnam, known as Vietnam Living Standard Survey (VLSS), and integrated with information drawn from other official sources collected by the Vietnam General Statistics Office (GSO). While all the LSMSs are designed to be representative at the national and regional level, their sample sizes differ (see World Bank, 1995; World Bank, 2001; GSO, 2002; GSO, 2004; GSO, 2006 for detailed information on sampling procedures). The samples drawn from the MRD are quite different across the various survey years $(1993,1998,2002,2004,2006)$.

We use these five cross-section data sets spanning a 13year period to construct two panel datasets. The first panel dataset [hereafter called panel I] is formed by combining information from the first two surveys 1993 and 1998, while the second [hereafter called panel II] is obtained by combining the last three surveys 2002, 2004 and 2006. Potentially, panel I consists of 1,600 observations, with 800 households from each survey, while panel II contains 945 observations with 305 households drawn from each survey. However, due to missing or incomplete data for some of the variables and/ or missing identifiers, the sample size reduces to 1,414 observations for panel I and 915 for panel II. Given the relatively small attrition rate it is unlikely that sample attrition plays a large role in terms of influencing the estimates.

\section{Research Methods}

\subsection{Model Specification - Dependent Variable}

The empirical work focuses on the temporal determinants of farm self-employment and non-farm wage employment (see Table 1). Following the discussion in section 2, the potential determinants of these two sources of employment are divided into two main categories: (i) variables that reflect household capacity to undertake non-farm activity, and (ii) variables that influence the incentive to diversify.

As discussed in the related literature, the most appropriate measures of diversification are either the shares of income earned from different sources or the time spent on different activities. Consistent with the conceptual framework sketched above where prices of commodities play an important role in determining household time-allocation decisions, the analysis here relies on time-based measure of diversification. Clearly, using an income-based measure is not reasonable as the income-based measures are a product of commodity prices and output produced.

Accordingly, the share of time spent in specific sources of employment is used as the dependent variable in our econometric model. Table 1 provides information on the time spent by households in different activities and as displayed, over time the main changes are in the share of time spent on farm self-employment and non-farm wage employment. In terms of estimation, since the share of time spent by households in each form of employment cannot be below zero or above one, a double-censored regression model, in particular a two-limit tobit model is used to analyze the determinants of time spent on farm employment and non-farm wage employment. Time spent on each activity is specified as below (for simplicity, indices for the ith household and the jth time share of each household in the sample are not included in the equation). 
Table 1: Mean of earning time shares among households in panel data sets, by types of employment

\begin{tabular}{|c|c|c|c|c|c|c|c|c|}
\hline & \multicolumn{2}{|c|}{$\begin{array}{c}\text { Farm } \\
\text { self-employment }\end{array}$} & \multicolumn{2}{|c|}{$\begin{array}{c}\text { Off-farm } \\
\text { self-employment }\end{array}$} & \multicolumn{2}{|c|}{$\begin{array}{c}\text { Farm wage } \\
\text { employment }\end{array}$} & \multicolumn{2}{|c|}{$\begin{array}{c}\text { Non-farm wage } \\
\text { employment }\end{array}$} \\
\hline & Mean & Std.dev. & Mean & Std.dev. & Mean & Std.dev. & Mean & Std.dev. \\
\hline Panel I $(\mathrm{N}=1,414)$ & .614 & .361 & .163 & .276 & .143 & .250 & .080 & .191 \\
\hline '93 sample $(\mathrm{N}=707)$ & .628 & .352 & .155 & .267 & .145 & .250 & .072 & .180 \\
\hline '98 sample ( $\mathrm{N}=707)$ & .600 & .369 & .171 & .284 & .141 & .250 & .088 & .202 \\
\hline Panel II (N = 915) & .491 & .436 & .177 & .327 & .136 & .302 & .196 & .316 \\
\hline '02 sample $(\mathrm{N}=305)$ & .484 & .440 & .173 & .323 & .180 & .332 & .163 & .290 \\
\hline ‘04 sample $(\mathrm{N}=305)$ & .498 & .435 & .169 & .322 & .126 & .302 & .207 & .323 \\
\hline \multirow[t]{2}{*}{ '06 sample $(\mathrm{N}=305)$} & .493 & .436 & .189 & .336 & .101 & .262 & .218 & .334 \\
\hline & Diff. & p-value & Diff. & p-value & Diff. & p-value & Diff. & $\mathrm{p}$-value \\
\hline Changes over '93-'98 & .027 & .1550 & .015 & .2949 & -.004 & .7596 & .016 & .1154 \\
\hline Changes over '02-'06 & .009 & .8101 & .017 & .5335 & -.079 & .0011 & .055 & .0325 \\
\hline
\end{tabular}

Note: Diff. stands for the mean difference.

$$
\begin{aligned}
& S^{*}=\beta_{0}+\beta_{1} X_{1}+\beta_{2} X_{2}+\ldots+\beta_{n} X_{n}+u \\
& S=\left\{\begin{array}{lll}
0 & \text { if } \quad S^{*} \leq 0 \\
1 \quad \text { if } & S^{*} \geq 1 \\
S^{*} & \text { if } & 0<S^{*} \leq 0
\end{array}\right.
\end{aligned}
$$

Here, $X_{1}, X_{2}, \ldots, X_{\mathrm{n}}$ denote independent variables that have a bearing on time allocation. $S^{*}$ is a latent variable indicating the desired share of time that a household would like to spend on each activity while $S$ is the observed share of time worked by a household in a specific type of employment in question. The relationship between the observed and latent variable is provided above and $\mathrm{u}$ is an error term, which is assumed to follow a standard normal distribution.

Since a tobit model is used, a decomposition approach suggested by McDonald and Mofitt (1980) may be used to obtain the marginal effects of the independent variables on the outcome. That is, a change in an independent variable has two effects-(i) it affects the conditional mean of $S^{*}$ in the part of the distribution between 0 and 1 and (ii) it affects the probability that the observation will fall in that part of the distribution. Mathematically, these effects can be displayed as below (Green, 2003, pp.764-773).

$$
\begin{aligned}
& \frac{\partial E[S \mid X]}{\partial X} \\
& =\operatorname{Prob}[0<S<1] \frac{\partial E[\mathrm{~S} \mid \mathrm{X}, 0<S<1]}{\partial X} \\
& +\partial E[S \mid \mathrm{X}, 0<S<1] \frac{\partial \operatorname{rob}[0<S<1]}{\partial X}
\end{aligned}
$$

Or, in a more visible form,

$$
\frac{\partial E[S \mid X]}{\partial X}=\beta \times \operatorname{Prob}\left[0<S^{*}<1\right]
$$

\subsection{Model Specification - Independent Variables}

Following Section 2, time spent on different activities is modeled as a function of household capacity variables and variables that reflect the incentive to diversify. As far as the former are concerned, household is captured by nine variables. Three of them capture the quantity of labor, that is, the number of male members in the age group 19-59, number of female members in the age group 19-54 and the number of children aged 15 to 18 . The first two variables include those individuals that are considered as part of the main labor force as is officially recognized by Vietnamese Labour Laws. The child group represents a supplementary source of labor. Statistics in Table 2 indicate that each rural household has less than three main workers and is gender balanced. In addition to the main labor force, there are 4-6 other members aged between 15 and 18 for every 10 rural households.

Several variables are used to capture the quality of the main labor force. Workers are first segmented by gender and further by four education attainment levels into eight sub-categories. These are men versus women without schooling, men versus women with primary education, men versus women with secondary education and male versus female with higher than secondary education (tertiary). Of the three educational categories, main workers with higher educational attainment account for the smallest proportion, 6-12 percent for males and 4-7 percent for females; the figures for secondary level education are 15-17 and 10-13 percent of the main labor force for men and women respectively; 
Table 2: Definition and statistics of independent variables in the panel samples

\begin{tabular}{|c|c|c|c|c|c|}
\hline \multirow{2}{*}{ Variables } & \multicolumn{2}{|c|}{ Panel I (1993/98) } & \multicolumn{3}{|c|}{ Panel II (2002/04/06) } \\
\hline & 1993 & 1998 & 2002 & 2004 & 2006 \\
\hline \multicolumn{6}{|l|}{ Household characteristics } \\
\hline Female head $=1$ & $\begin{array}{l}.233 \\
(.423) \\
\end{array}$ & $\begin{array}{c}.256 \\
(.437) \\
\end{array}$ & $\begin{array}{c}0.208 \\
(0.406)\end{array}$ & $\begin{array}{c}0.217 \\
(0.413)\end{array}$ & $\begin{array}{c}0.214 \\
(0.411) \\
\end{array}$ \\
\hline Ethnic minority $=1$ & $\begin{array}{l}.100 \\
(.301) \\
\end{array}$ & $\begin{array}{l}.100 \\
(.301) \\
\end{array}$ & $\begin{array}{c}0.051 \\
(0.221) \\
\end{array}$ & $\begin{array}{c}0.051 \\
(0.221) \\
\end{array}$ & $\begin{array}{c}0.051 \\
(0.221) \\
\end{array}$ \\
\hline Household size & $\begin{array}{l}5.55 \\
(2.24) \\
\end{array}$ & $\begin{array}{c}5.19 \\
(2.00) \\
\end{array}$ & $\begin{array}{c}4.581 \\
(1.792)\end{array}$ & $\begin{array}{c}4.364 \\
(1.719)\end{array}$ & $\begin{array}{c}4.153 \\
(1.649) \\
\end{array}$ \\
\hline \multicolumn{6}{|l|}{ Household labor resource } \\
\hline $\begin{array}{l}\text { Number of male members } \\
19-59 \text { age group }(A)\end{array}$ & $\begin{array}{l}1.117 \\
(.743) \\
\end{array}$ & $\begin{array}{l}1.150 \\
(.740) \\
\end{array}$ & $\begin{array}{c}1.265 \\
(0.736) \\
\end{array}$ & $\begin{array}{c}1.259 \\
(0.760) \\
\end{array}$ & $\begin{array}{c}1.246 \\
(0.780) \\
\end{array}$ \\
\hline $\begin{array}{l}\text { Number of female members } \\
19-54 \text { age group (B) }\end{array}$ & $\begin{array}{l}1.187 \\
(.699)\end{array}$ & $\begin{array}{l}1.209 \\
(.740)\end{array}$ & $\begin{array}{c}1.163 \\
(0.722)\end{array}$ & $\begin{array}{c}1.083 \\
(0.679)\end{array}$ & $\begin{array}{c}1.070 \\
(0.722)\end{array}$ \\
\hline $\begin{array}{l}\text { Number of members } \\
15-18 \text { age group }\end{array}$ & $\begin{array}{c}.569 \\
(.762) \\
\end{array}$ & $\begin{array}{c}.627 \\
(.752)\end{array}$ & $\begin{array}{c}0.482 \\
(0.734) \\
\end{array}$ & $\begin{array}{c}0.447 \\
(0.649)\end{array}$ & $\begin{array}{c}0.364 \\
(0.562) \\
\end{array}$ \\
\hline $\begin{array}{l}\text { Share of main labor force }(A+B) \text { : } \\
\text { males with primary education }\end{array}$ & $\begin{array}{l}.204 \\
(.247)\end{array}$ & $\begin{array}{c}.220 \\
(.260)\end{array}$ & $\begin{array}{c}0.212 \\
(0.267)\end{array}$ & $\begin{array}{c}0.215 \\
(0.276)\end{array}$ & $\begin{array}{c}0.171 \\
(0.242)\end{array}$ \\
\hline $\begin{array}{l}\text { Share of main labor force }(A+B) \text { : } \\
\text { females with primary education }\end{array}$ & $\begin{array}{l}.290 \\
(.278) \\
\end{array}$ & $\begin{array}{c}.292 \\
(.279) \\
\end{array}$ & $\begin{array}{c}0.241 \\
(0.252)\end{array}$ & $\begin{array}{c}0.198 \\
(0.234)\end{array}$ & $\begin{array}{c}0.188 \\
(0.234)\end{array}$ \\
\hline $\begin{array}{l}\text { Share of main labor force }(A+B) \text { : } \\
\text { males with secondary education }\end{array}$ & $\begin{array}{l}.154 \\
(.243) \\
\end{array}$ & $\begin{array}{l}.148 \\
(.235) \\
\end{array}$ & $\begin{array}{c}0.169 \\
(0.235) \\
\end{array}$ & $\begin{array}{c}0.159 \\
(0.233) \\
\end{array}$ & $\begin{array}{c}0.169 \\
(0.257)\end{array}$ \\
\hline $\begin{array}{l}\text { Share of main labor force }(A+B) \text { : } \\
\text { females with secondary education }\end{array}$ & $\begin{array}{c}.101 \\
(.214) \\
\end{array}$ & $\begin{array}{l}.107 \\
(.209) \\
\end{array}$ & $\begin{array}{c}0.119 \\
(0.214) \\
\end{array}$ & $\begin{array}{c}0.133 \\
(0.220) \\
\end{array}$ & $\begin{array}{c}0.124 \\
(0.221) \\
\end{array}$ \\
\hline $\begin{array}{l}\text { Share of main labor force }(A+B) \text { : } \\
\text { males with tertiary education }\end{array}$ & $\begin{array}{c}.058 \\
(.167) \\
\end{array}$ & $\begin{array}{c}.055 \\
(.148) \\
\end{array}$ & $\begin{array}{c}0.099 \\
(0.214)\end{array}$ & $\begin{array}{c}0.107 \\
(0.218)\end{array}$ & $\begin{array}{c}0.126 \\
(0.240) \\
\end{array}$ \\
\hline $\begin{array}{l}\text { Share of main labor force }(A+B) \text { : } \\
\text { females with tertiary education }\end{array}$ & $\begin{array}{l}.044 \\
(.155) \\
\end{array}$ & $\begin{array}{c}.039 \\
(.148) \\
\end{array}$ & $\begin{array}{c}0.054 \\
(0.154) \\
\end{array}$ & $\begin{array}{c}0.059 \\
(0.160) \\
\end{array}$ & $\begin{array}{c}0.067 \\
(0.167)\end{array}$ \\
\hline \multicolumn{6}{|l|}{ Household non-labor capitals } \\
\hline Farm size (hectare) & $\begin{array}{c}.912 \\
(1.03) \\
\end{array}$ & $\begin{array}{l}.860 \\
(.99) \\
\end{array}$ & $\begin{array}{c}0.764 \\
(1.096) \\
\end{array}$ & $\begin{array}{c}0.728 \\
(0.934) \\
\end{array}$ & $\begin{array}{c}0.731 \\
(0.951) \\
\end{array}$ \\
\hline $\begin{array}{l}\text { Amount of land with land-use rights } \\
\text { certificate (hectare) }\end{array}$ & $\begin{array}{l}.845 \\
(.973) \\
\end{array}$ & $\begin{array}{c}.849 \\
(.965) \\
\end{array}$ & $\begin{array}{c}0.577 \\
(0.900) \\
\end{array}$ & \begin{tabular}{|c|}
0.684 \\
$(0.940)$ \\
\end{tabular} & $\begin{array}{c}0.713 \\
(0.960) \\
\end{array}$ \\
\hline $\begin{array}{l}\text { Value of houses and real estate (million } \\
\text { VND)(a) }\end{array}$ & $\begin{array}{c}8.522 \\
(13.62) \\
\end{array}$ & $\begin{array}{l}13.772 \\
(17.11) \\
\end{array}$ & $31.211(49.01)$ & $45.234(67.65)$ & $\begin{array}{l}34.308 \\
(37.64) \\
\end{array}$ \\
\hline Number of current migrants & $\begin{array}{c}.267 \\
(.705) \\
\end{array}$ & $\begin{array}{c}.246 \\
(.649) \\
\end{array}$ & - & $\begin{array}{c}0.220 \\
(0.588) \\
\end{array}$ & $\begin{array}{c}0.006 \\
(0.080)\end{array}$ \\
\hline \multicolumn{6}{|l|}{ Communal/provincial level variables } \\
\hline Access to paved road $=1^{(\mathrm{b})}$ & $\begin{array}{c}.409 \\
(.492)\end{array}$ & $\begin{array}{l}.332 \\
(.471) \\
\end{array}$ & $\begin{array}{c}0.339 \\
(0.474) \\
\end{array}$ & $\begin{array}{c}0.383 \\
(0.487)\end{array}$ & $\begin{array}{r}0.511 \\
(0.501) \\
\end{array}$ \\
\hline Own irrigation system $=1$ & $\begin{array}{l}- \\
- \\
\end{array}$ & $\begin{array}{l}- \\
- \\
\end{array}$ & - & $\begin{array}{c}0.623 \\
(0.485) \\
\end{array}$ & $\begin{array}{c}0.623 \\
(0.485) \\
\end{array}$ \\
\hline Number of natural disasters & $\begin{array}{c}3.24 \\
(1.95) \\
\end{array}$ & $\begin{array}{l}5.29 \\
(6.31) \\
\end{array}$ & - & $\begin{array}{c}1.387 \\
(1.069)\end{array}$ & $\begin{array}{c}1.262 \\
(1.130)\end{array}$ \\
\hline Price of paddy (thousand VND/kg)(c) & $\begin{array}{l}1.008 \\
(.099) \\
\end{array}$ & $\begin{array}{l}1.235 \\
.091)\end{array}$ & $\begin{array}{c}1.973 \\
(0.207)\end{array}$ & $\begin{array}{c}1.837 \\
(0.165)\end{array}$ & $\begin{array}{c}2.212 \\
(0.181)\end{array}$ \\
\hline Number of observations & 707 & 707 & 305 & 305 & 305 \\
\hline
\end{tabular}

Notes: Figures in parentheses are the standard deviation of the mean.

(a) The value of houses and real estate is measured in real January 1993 prices.

(b) It is a road for motor vehicles for 1993 while a road for cars for the later years.

(c) The price of paddy is measured in real January 1993 prices for pannel I and in real January 2002 prices for pannel II. 
the figures for primary education are 17-22 and 19-29 for males and females, respectively. The descriptive statistics show evidence of labor quality improvement in rural MRD over 1993-2006; that is over time there is an increase in the proportion of males and females with secondary and higher levels of education and a decline in the proportion of individuals with only primary education.

Farm size is used as a proxy for physical capital and access to financial capital. It is defined as the total amount of land that a household has for agricultural production including a household's own landholdings and land that has been rented in. On average, each household does farming on less than 0.9 hectare in 1993 and about 0.7 hectare in 2006. Over time there is a moderate decline in farm size. It is possible that this decline provides a motivation, more particularly a push factor, which may drive households from farm self-employment to alternative sources of employment. Thus, farm size may reflect not just a household's capacity to diversify but the decline over time may be viewed in terms of providing an incentive to diversify.

In addition to farm size, variables such as the size of the landholding with land-use right certificate and the value of a household's dwelling and other types of real estate are used to proxy household financial holding as well as access to credit. In Vietnam, an official land-use right certificate is regarded as appropriate collateral to get loans from banks. In reality, households can use these types of assets to access both formal and informal credit markets. Therefore, households owning more land and real estate have the financial capital and the ability to access credit markets that may be needed in order to diversify. Figures in Table 2 show an increase in the average value of houses and other real estates over time. In terms of land-use certificates almost all households have these for their entire landholding.

Social capital is a difficult variable to operationalize. To capture the availability of access to new information and new ideas I use the number of current migrants per household. These are members of a household who have been away from the household for at least one month over the past twelve months preceding the survey. The average quantity of migrants is quite small and has a value of 0.27 in 1993 and 0.006 in 2006. Information on this variable was not collected in 2002. Attempts were also made to include variables such as individual's membership of the Vietnamese Communist Party in the specifications. Unfortunately, the number of households (individuals) having this honor is too few to create a variable.

We now turn to variables that capture the incentive to diversify. Theoretically, such incentives may be measured at the household-level or at a higher level of aggregation (commune-level). The variables included are commune access to paved road, commune access to irrigation systems and the number of natural disasters experienced in a commune. Access to physical infrastructure/roads is expected to lower transport and transaction costs and influence time-allocation decisions. Access to an irrigation system reduces reliance on rainfall and thereby reduces the risks associated with rain-fed agricultural production. An increase in the number of natural disasters experienced by a commune may provide an incentive to move away from vulnerable agricultural production.

Since rice is the dominant agricultural product in the MRD, commune level rice prices are included as a measure of the incentive to diversify. Data on rice prices are collected from commune surveys for the years 1993 and 1998 and monthly statistics available from the GSO for the remaining years. The real prices displayed in Table 2 show a sharp increase between 1993 and 1998 and between 2002 and 2006 both.

In addition to the variables discussed above, household characteristics such as household size, gender of household and ethnic group, are included in the empirical model. These variables are included to control for the role of household demographic and ethnic attributes in influencing timeallocation patterns.

\section{Results and Discussion}

Tobit and OLS estimates, using both a random effects (RE) and a fixed effects (FE) specification are used to estimate the impact of various characteristics on timeallocation patterns (see Tables 3 and 4). For both panels the results are qualitatively similar, however, given the greater variation in Panel II, the discussion below focuses on Panel II estimates.

Table 4 shows that regardless of whether one considers the tobit or OLS estimates, they appear to be delivering the same message. Given the relatively small sample size and the limited temporal variation in some of the characteristics it was difficult to obtain marginal effects based on a TobitFE model. While both sets of estimates are provided, a Hausman test supports the use of a fixed effects specification in the case of the determinants of farming and the use of a RE specification in the case of non-farming activities. Since the two sets of estimates do not differ substantially, the discussion of results is based on the OLS-FE estimates presented in Table 4.

The OLS-FE reveals that female-headed households are less likely to engage in farming activities. At the same time larger households and those with more workers, especially younger workers in the age range 15-18 are increasingly likely to spend time on non-farming activities. For instance, a unit increase in the number of household members in the 15-18 age group is associated with a reduction in farming activities of 5.2 percentage points and a corresponding increasing in non-farming wage employment of about 5 percentage points. 
Table 3: Determinants of the temporal income diversification, 1993/98

\begin{tabular}{|c|c|c|c|c|c|c|c|c|}
\hline \multirow{3}{*}{ Variables } & \multicolumn{4}{|c|}{ Tobit model with random effects } & \multicolumn{4}{|c|}{ OLS model with random and fixed effects } \\
\hline & \multicolumn{2}{|c|}{$\begin{array}{c}\text { Farm } \\
\text { self-employment }\end{array}$} & \multicolumn{2}{|c|}{$\begin{array}{c}\text { Non-farm } \\
\text { wage employment }\end{array}$} & \multicolumn{2}{|c|}{$\begin{array}{c}\text { Farm } \\
\text { self-employment }\end{array}$} & \multicolumn{2}{|c|}{$\begin{array}{c}\text { Non-farm } \\
\text { wage employment }\end{array}$} \\
\hline & Coef. & Effect & Coef. & Effect & RE. & FE. & RE. & FE. \\
\hline \multicolumn{9}{|l|}{$\begin{array}{l}\text { Household } \\
\text { characteristics }\end{array}$} \\
\hline Female head $=1$ & $\begin{array}{l}-.066^{*} \\
(.034) \\
\end{array}$ & $\begin{array}{l}-.048^{*} \\
(.025) \\
\end{array}$ & $\begin{array}{c}.049 \\
(.052) \\
\end{array}$ & $\begin{array}{c}.011 \\
(.012) \\
\end{array}$ & $\begin{array}{l}-.046^{* *} \\
(.023)\end{array}$ & $\begin{array}{l}.003 \\
(.043) \\
\end{array}$ & $\begin{array}{l}.008 \\
(.014) \\
\end{array}$ & $\begin{array}{l}-.047^{*} \\
(.028) \\
\end{array}$ \\
\hline Ethnic minority $=1$ & $\begin{array}{l}-.083^{*} \\
(.050)\end{array}$ & $\begin{array}{l}-.061 \\
(.037)\end{array}$ & $\begin{array}{l}.074 \\
(.078)\end{array}$ & $\begin{array}{l}.017 \\
(.019)\end{array}$ & $\begin{array}{l}-.048 \\
(.034)\end{array}$ & $\begin{array}{l}.000 \\
(.000)\end{array}$ & $\begin{array}{l}-.003 \\
(.020)\end{array}$ & $\begin{array}{c}.000 \\
(.000)\end{array}$ \\
\hline Household size & $\begin{array}{l}-.065 \\
(.024) \\
\end{array}$ & $\begin{array}{l}-.047 \\
(.018) \\
\end{array}$ & $\begin{array}{l}.051 \\
(.040) \\
\end{array}$ & $\begin{array}{l}.011 \\
(.008) \\
\end{array}$ & $\begin{array}{l}-.048^{* \star *} \\
(.016)\end{array}$ & $\begin{array}{l}-.036 \\
(.023) \\
\end{array}$ & $\begin{array}{l}.008 \\
(.010) \\
\end{array}$ & $\begin{array}{l}.020 \\
(.015) \\
\end{array}$ \\
\hline $\begin{array}{l}\text { Household size } \\
\text { squared }\end{array}$ & $\begin{array}{l}.005^{* \star *} \\
(.002)\end{array}$ & $\begin{array}{l}.004^{* * *} \\
(.001)\end{array}$ & $\begin{array}{l}-.005^{*} \\
(.003) \\
\end{array}$ & $\begin{array}{l}-.001^{\star} \\
(.001) \\
\end{array}$ & $\begin{array}{l}.004^{* * *} \\
(.001)\end{array}$ & $\begin{array}{l}.003^{*} \\
(.002) \\
\end{array}$ & $\begin{array}{l}-.001 \\
(.001) \\
\end{array}$ & $\begin{array}{l}-.002^{*} \\
(.001)\end{array}$ \\
\hline \multicolumn{9}{|l|}{$\begin{array}{l}\text { Household labor } \\
\text { resource }\end{array}$} \\
\hline $\begin{array}{l}\text { Number of male } \\
\text { members } \\
19-59 \text { age group }(A)\end{array}$ & $\begin{array}{l}-.041 \\
(.026)\end{array}$ & $\begin{array}{l}-.030 \\
(.019)\end{array}$ & $\begin{array}{l}.124^{* * *} \\
(.039)\end{array}$ & $\begin{array}{l}.026^{* * *} \\
(.008)\end{array}$ & $\begin{array}{l}-.023 \\
(.017)\end{array}$ & $\begin{array}{l}.000 \\
(.023)\end{array}$ & $\begin{array}{l}.032^{* * *} \\
(.010)\end{array}$ & $\begin{array}{l}.029^{* *} \\
(.015)\end{array}$ \\
\hline $\begin{array}{l}\text { Number of female } \\
\text { members } \\
19-54 \text { age group (B) }\end{array}$ & $\begin{array}{l}-.042^{*} \\
(.025)\end{array}$ & $\begin{array}{l}-.030^{*} \\
(.018)\end{array}$ & $\begin{array}{l}.024 \\
(.038)\end{array}$ & $\begin{array}{l}.005 \\
(.008)\end{array}$ & $\begin{array}{l}-.024 \\
(.017)\end{array}$ & $\begin{array}{l}-.042^{*} \\
(.022)\end{array}$ & $\begin{array}{l}-.005 \\
(.010)\end{array}$ & $\begin{array}{l}-.001 \\
(.014)\end{array}$ \\
\hline $\begin{array}{l}\text { Number of members } \\
15-18 \text { age group }\end{array}$ & $\begin{array}{l}-.009 \\
(.017) \\
\end{array}$ & $\begin{array}{l}-.006 \\
(.013) \\
\end{array}$ & $\begin{array}{l}.051^{*} \\
(.028) \\
\end{array}$ & $\begin{array}{l}.011^{*} \\
(.006) \\
\end{array}$ & $\begin{array}{l}-.003 \\
(.011) \\
\end{array}$ & $\begin{array}{l}-.012 \\
(.014) \\
\end{array}$ & $\begin{array}{l}.006 \\
(.007) \\
\end{array}$ & $\begin{array}{l}.006 \\
(.009)\end{array}$ \\
\hline $\begin{array}{l}\text { Share of main labor } \\
\text { force }(A+B) \text { : } \\
\text { males with primary } \\
\text { education }\end{array}$ & $\begin{array}{l}.014 \\
(.075)\end{array}$ & $\begin{array}{l}.010 \\
(.054)\end{array}$ & $\begin{array}{l}.030 \\
(.131)\end{array}$ & $\begin{array}{l}.006 \\
(.027)\end{array}$ & $\begin{array}{l}.019 \\
(.050)\end{array}$ & $\begin{array}{l}-.040 \\
(.065)\end{array}$ & $\begin{array}{l}-.011 \\
(.030)\end{array}$ & $\begin{array}{l}-.020 \\
(.042)\end{array}$ \\
\hline $\begin{array}{l}\text { Share of main labor } \\
\text { force }(A+B) \text { : } \\
\text { females with primary } \\
\text { education }\end{array}$ & $\begin{array}{l}.003 \\
(.062)\end{array}$ & $\begin{array}{l}.002 \\
(.045)\end{array}$ & $\begin{array}{l}.143 \\
(.108)\end{array}$ & $\begin{array}{l}.030 \\
(.023)\end{array}$ & $\begin{array}{c}.013 \\
(.042)\end{array}$ & $\begin{array}{l}.038 \\
(.060)\end{array}$ & $\begin{array}{l}.023 \\
(.025)\end{array}$ & $\begin{array}{l}.022 \\
(.038)\end{array}$ \\
\hline $\begin{array}{l}\text { Share of main labor } \\
\text { force }(A+B) \text { : } \\
\text { males with secondary } \\
\text { education }\end{array}$ & $\begin{array}{l}-.059 \\
(.078)\end{array}$ & $\begin{array}{l}-.043 \\
(.056)\end{array}$ & $\begin{array}{l}.243^{*} \\
(.130)\end{array}$ & $\begin{array}{l}.051^{\star} \\
(.027)\end{array}$ & $\begin{array}{l}-.004 \\
(.052)\end{array}$ & $\begin{array}{l}-.113 \\
(.071)\end{array}$ & $\begin{array}{l}.026 \\
(.031)\end{array}$ & $\begin{array}{c}.045 \\
(.045)\end{array}$ \\
\hline $\begin{array}{l}\text { Share of main labor } \\
\text { force }(A+B) \text { : } \\
\text { females with } \\
\text { secondary education }\end{array}$ & $\begin{array}{l}-.134^{*} \\
(.079)\end{array}$ & $\begin{array}{l}-.097^{*} \\
(.057)\end{array}$ & $\begin{array}{l}.264^{* *} \\
(.129)\end{array}$ & $\begin{array}{l}.055^{\star *} \\
(.027)\end{array}$ & $\begin{array}{l}-.083 \\
(.053)\end{array}$ & $\begin{array}{l}-.041 \\
(.079)\end{array}$ & $\begin{array}{c}.045 \\
(.031)\end{array}$ & $\begin{array}{c}.001 \\
(.051)\end{array}$ \\
\hline $\begin{array}{l}\text { Share of main labor } \\
\text { force }(A+B) \text { : } \\
\text { males with tertiary } \\
\text { education }\end{array}$ & $\begin{array}{l}-.087 \\
(.102)\end{array}$ & $\begin{array}{l}-.063 \\
(.074)\end{array}$ & $\begin{array}{l}.478^{* * *} \\
(.159)\end{array}$ & $\begin{array}{l}.100^{\star * *} \\
(.033)\end{array}$ & $\begin{array}{l}-.048 \\
(.068)\end{array}$ & $\begin{array}{c}-.191^{*} \\
(.098)\end{array}$ & $\begin{array}{l}.098^{* *} \\
(.040)\end{array}$ & $\begin{array}{l}.125^{* *} \\
(.063)\end{array}$ \\
\hline $\begin{array}{l}\text { Share of main labor } \\
\text { force }(A+B) \text { : } \\
\text { females with tertiary } \\
\text { education }\end{array}$ & $\begin{array}{l}-.184^{*} \\
(.103)\end{array}$ & $\begin{array}{l}-.133^{*} \\
(.075)\end{array}$ & $\begin{array}{l}.801^{* * *} \\
(.152)\end{array}$ & $\begin{array}{l}.167^{* * *} \\
(.032)\end{array}$ & $\begin{array}{l}-.127^{*} \\
(.069)\end{array}$ & $\begin{array}{l}-.061 \\
(.114)\end{array}$ & $\begin{array}{l}.273^{* * *} \\
(.041)\end{array}$ & $\begin{array}{c}.016 \\
(.073)\end{array}$ \\
\hline
\end{tabular}

Cont... 


\begin{tabular}{|c|c|c|c|c|c|c|c|c|}
\hline \multicolumn{9}{|l|}{$\begin{array}{l}\text { Household non-labor } \\
\text { capitals }\end{array}$} \\
\hline Farm size (hectare) & $\begin{array}{l}.346^{* * * *} \\
(.025)\end{array}$ & $\begin{array}{l}.251^{* * *} \\
(.018)\end{array}$ & $\begin{array}{l}-.161 \\
(.037)\end{array}$ & $\begin{array}{l}-.034 \\
(.008)\end{array}$ & $\begin{array}{l}.235^{* * *} \\
(.016)\end{array}$ & $\begin{array}{l}.078^{* * *} \\
(.024)\end{array}$ & $\begin{array}{l}-.045^{\text {twt }} \\
(.009)\end{array}$ & $\begin{array}{l}-.025 \\
(.016)\end{array}$ \\
\hline Farm size squared & $\begin{array}{l}-.032 \\
(.004) \\
\end{array}$ & $\begin{array}{l}-.023 \\
(.003) \\
\end{array}$ & $\begin{array}{l}.015^{* *} \\
(.006) \\
\end{array}$ & $\begin{array}{l}.003^{* *} \\
(.001) \\
\end{array}$ & $\begin{array}{l}-.022^{*+*+} \\
(.002) \\
\end{array}$ & $\begin{array}{l}-.004 \\
(.003) \\
\end{array}$ & $\begin{array}{l}.004^{+*+*} \\
(.002) \\
\end{array}$ & $\begin{array}{l}.002 \\
(.002) \\
\end{array}$ \\
\hline $\begin{array}{l}\text { Value of houses and } \\
\text { real estate (million } \\
\text { VND) }\end{array}$ & $\begin{array}{l}-.000 \\
(.001)\end{array}$ & $\begin{array}{l}-.000 \\
(.000)\end{array}$ & $\begin{array}{l}.000 \\
(.001)\end{array}$ & $\begin{array}{l}.000 \\
(.000)\end{array}$ & $\begin{array}{l}-.000 \\
(.000)\end{array}$ & $\begin{array}{l}.001 \\
(.001)\end{array}$ & $\begin{array}{l}.000 \\
(.000)\end{array}$ & $\begin{array}{l}.000 \\
(.000)\end{array}$ \\
\hline $\begin{array}{l}\text { Number of current } \\
\text { migrants }\end{array}$ & $\begin{array}{l}-.092 \\
(.017) \\
\end{array}$ & $\begin{array}{l}-.067 \\
(.012) \\
\end{array}$ & $\begin{array}{l}.116^{* * * *} \\
(.026) \\
\end{array}$ & $\begin{array}{l}.024^{* * * *} \\
(.005) \\
\end{array}$ & $\begin{array}{l}-.064^{* * *} \\
(.012) \\
\end{array}$ & $\begin{array}{l}-.033^{* *} \\
(.014) \\
\end{array}$ & $\begin{array}{l}.025^{* * *} \\
(.007) \\
\end{array}$ & $\begin{array}{l}.022^{* *} \\
(.009) \\
\end{array}$ \\
\hline \multicolumn{9}{|l|}{$\begin{array}{l}\text { Communal/provincial } \\
\text { level variables }\end{array}$} \\
\hline $\begin{array}{l}\text { Access to paved } \\
\text { roads }=1^{(\mathrm{a})}\end{array}$ & $\begin{array}{l}-.078 \\
(.027)\end{array}$ & $\begin{array}{l}-.057 \\
(.020)\end{array}$ & $\begin{array}{l}.126^{* * * *} \\
(.042)\end{array}$ & $\begin{array}{l}.027^{*+*} \\
(.010)\end{array}$ & $\begin{array}{l}-.058^{*+*} \\
(.018)\end{array}$ & $\begin{array}{l}-.008 \\
(.023)\end{array}$ & $\begin{array}{l}.034^{* * *} \\
(.011)\end{array}$ & $\begin{array}{l}.006 \\
(.014)\end{array}$ \\
\hline $\begin{array}{l}\text { Number of natural } \\
\text { disasters }\end{array}$ & $\begin{array}{l}-.003 \\
(.002)\end{array}$ & $\begin{array}{l}-.002 \\
(.002)\end{array}$ & $\begin{array}{l}-.002 \\
(.004)\end{array}$ & $\begin{array}{l}-.000 \\
(.001)\end{array}$ & $\begin{array}{l}-.002 \\
(.002)\end{array}$ & $\begin{array}{l}.000 \\
(.000)\end{array}$ & $\begin{array}{l}.000 \\
(.001)\end{array}$ & $\begin{array}{l}.000 \\
(.000)\end{array}$ \\
\hline $\begin{array}{l}\text { Price of paddy } \\
\text { (thousand VND/kg) }\end{array}$ & $\begin{array}{l}.542^{* * *} \\
(.124)\end{array}$ & $\begin{array}{l}.393^{*+* *} \\
(.090)\end{array}$ & $\begin{array}{l}-.188 \\
(.199)\end{array}$ & $\begin{array}{l}-.039 \\
(.042)\end{array}$ & $\begin{array}{l}.376^{* * *} \\
(.082)\end{array}$ & $\begin{array}{l}.215^{* *} \\
(.092)\end{array}$ & $\begin{array}{l}-.046 \\
(.050)\end{array}$ & $\begin{array}{l}-.017 \\
(.059)\end{array}$ \\
\hline \multicolumn{9}{|l|}{ Time dummy variable } \\
\hline $\mathrm{T}=1998$ & $\begin{array}{l}-.137 \\
(.034)\end{array}$ & $\begin{array}{l}-.099 \\
(.025)\end{array}$ & $\begin{array}{l}.089 \\
(.058)\end{array}$ & $\begin{array}{l}.019 \\
(.012)\end{array}$ & $\begin{array}{l}-.101^{*+*+} \\
(.023)\end{array}$ & $\begin{array}{l}-.061^{\text {** }} \\
(.025)\end{array}$ & $\begin{array}{l}.023 \\
(.014)\end{array}$ & $\begin{array}{l}.013 \\
(.016)\end{array}$ \\
\hline Constant & $\begin{array}{l}.284^{*} \\
(.152)\end{array}$ & & $\begin{array}{l}-.704 \\
(.251)\end{array}$ & & $\begin{array}{l}.334^{* * *} \\
(.101)\end{array}$ & $\begin{array}{l}.549^{* * *} \\
(.122)\end{array}$ & $\begin{array}{l}.054 \\
(.061)\end{array}$ & $\begin{array}{l}.012 \\
(.079)\end{array}$ \\
\hline Number of groups & \multicolumn{2}{|c|}{704} & \multicolumn{2}{|c|}{704} & 704 & 704 & 704 & 704 \\
\hline $\begin{array}{l}\text { Number of } \\
\text { observations }\end{array}$ & \multicolumn{2}{|c|}{1,403} & \multicolumn{2}{|c|}{1,403} & 1,403 & 1,403 & 1,403 & 1,403 \\
\hline $\begin{array}{l}\text { - Left-censored (at } \\
\text { zero) }\end{array}$ & \multicolumn{2}{|c|}{146} & \multicolumn{2}{|c|}{1,079} & & & & \\
\hline - Uncensored & \multicolumn{2}{|c|}{897} & \multicolumn{2}{|c|}{312} & & & & \\
\hline $\begin{array}{l}\text { - Right-censored (at } \\
\text { one) }\end{array}$ & \multicolumn{2}{|c|}{360} & \multicolumn{2}{|c|}{12} & & & & \\
\hline Wald chi2(30) & \multicolumn{2}{|c|}{326.09} & \multicolumn{2}{|c|}{129.53} & & & & \\
\hline Prob > chi2 & \multicolumn{2}{|c|}{0.0000} & \multicolumn{2}{|c|}{0.0000} & & & & \\
\hline Log likelihood & \multicolumn{2}{|c|}{-909.6002} & \multicolumn{2}{|c|}{-622.6050} & & & & \\
\hline $\operatorname{Pr}\left(0<S^{*}<1\right)$ & \multicolumn{2}{|c|}{0.7245} & \multicolumn{2}{|c|}{0.2090} & & & & \\
\hline Wald chi2 & & & & & 403.44 & & 169.42 & \\
\hline Prob>chi2 & & & & & .0000 & & .0000 & \\
\hline $\mathrm{F}$ & & & & & & 2.52 & & 2.08 \\
\hline Prob $>F$ & & & & & & 0.0004 & & 0.0045 \\
\hline R-squared & & & & & .3070 & .0658 & .1392 & .0549 \\
\hline Hausman test-chi2 & & & & & \multicolumn{2}{|c|}{119.37} & \multicolumn{2}{|c|}{39.78} \\
\hline Prob>chi2 & & & & & \multicolumn{2}{|c|}{0.0000} & \multicolumn{2}{|c|}{0.0035} \\
\hline
\end{tabular}

Notes: ${ }^{*},{ }^{* *},{ }^{* * *}$ respectively denote statistically significant at, at least the 10,5 , and 1 percent level.

(a) It is a road for motor vehicles for 1993 while a road for cars for 1998. 
Table 4: Determinants of the temporal income diversification, 2002/04/06

\begin{tabular}{|c|c|c|c|c|c|c|c|c|}
\hline \multirow{3}{*}{ Variables } & \multicolumn{4}{|c|}{ Tobit model with random effects } & \multicolumn{4}{|c|}{$\begin{array}{l}\text { OLS model with random and fixed } \\
\text { effects }\end{array}$} \\
\hline & \multicolumn{2}{|c|}{$\begin{array}{l}\text { Farm } \\
\text { self-employment }\end{array}$} & \multicolumn{2}{|c|}{$\begin{array}{c}\text { Non-farm } \\
\text { wage } \\
\text { employment }\end{array}$} & \multicolumn{2}{|c|}{$\begin{array}{l}\text { Farm } \\
\text { self-employment }\end{array}$} & \multicolumn{2}{|c|}{$\begin{array}{l}\text { Non-farm } \\
\text { wage } \\
\text { employment }\end{array}$} \\
\hline & Coef. & Effect & Coef. & Effect & RE. & FE. & RE. & FE. \\
\hline \multicolumn{9}{|l|}{ Household characteristics } \\
\hline Female head $=1$ & $\begin{array}{l}-.275^{* \star} \\
(.114)\end{array}$ & $\begin{array}{l}-.116^{\star *} \\
(.047)\end{array}$ & $\begin{array}{l}.119 \\
(.107) \\
\end{array}$ & $\begin{array}{c}.032 \\
(.030) \\
\end{array}$ & $\begin{array}{l}-.097^{* \star *} \\
(.037)\end{array}$ & $\begin{array}{l}-.008 \\
(.072)\end{array}$ & $\begin{array}{l}.032 \\
(.031)\end{array}$ & $\begin{array}{l}.004 \\
(.060)\end{array}$ \\
\hline Ethnic minority = 1 & $\begin{array}{l}-.368 \\
(.240)\end{array}$ & $\begin{array}{l}-.153 \\
(.097)\end{array}$ & $\begin{array}{l}-.284 \\
(.260)\end{array}$ & $\begin{array}{l}-.063 \\
(.047)\end{array}$ & $\begin{array}{l}-.126 \\
(.077)\end{array}$ & $\begin{array}{l}.000 \\
(.000)\end{array}$ & $\begin{array}{l}-.036 \\
(.066)\end{array}$ & $\begin{array}{l}.000 \\
(.000)\end{array}$ \\
\hline Household size & $\begin{array}{l}-.197^{\star *} \\
(.098)\end{array}$ & $\begin{array}{l}-.083^{\star \star} \\
(.041)\end{array}$ & $\begin{array}{c}.072 \\
(.086)\end{array}$ & $\begin{array}{c}.019 \\
(.022)\end{array}$ & $\begin{array}{l}-.072^{* \star} \\
(.030)\end{array}$ & $\begin{array}{l}-.065^{*} \\
(.038)\end{array}$ & $\begin{array}{l}-.003 \\
(.025)\end{array}$ & $\begin{array}{l}.012 \\
(.031)\end{array}$ \\
\hline Household size squared & $\begin{array}{c}.011 \\
(.009)\end{array}$ & $\begin{array}{c}.005 \\
(.004)\end{array}$ & $\begin{array}{l}-.002 \\
(.007)\end{array}$ & $\begin{array}{l}-.000 \\
(.002)\end{array}$ & $\begin{array}{l}.005^{*} \\
(.003)\end{array}$ & $\begin{array}{l}.003 \\
(.003) \\
\end{array}$ & $\begin{array}{c}.002 \\
(.002)\end{array}$ & $\begin{array}{l}.000 \\
(.003)\end{array}$ \\
\hline \multicolumn{9}{|l|}{ Household labor resource } \\
\hline $\begin{array}{l}\text { Number of male members } \\
19-59 \text { age group }(A)\end{array}$ & $\begin{array}{l}-.010 \\
(.080)\end{array}$ & $\begin{array}{l}-.004 \\
(.034) \\
\end{array}$ & $\begin{array}{c}.111 \\
(.071) \\
\end{array}$ & $\begin{array}{c}.029 \\
(.018) \\
\end{array}$ & $\begin{array}{l}-.012 \\
(.027) \\
\end{array}$ & $\begin{array}{l}-.043 \\
(.034) \\
\end{array}$ & $\begin{array}{l}.037^{*} \\
(.022) \\
\end{array}$ & $\begin{array}{r}.039 \\
(.028) \\
\end{array}$ \\
\hline $\begin{array}{l}\text { Number of female members } \\
19-54 \text { age group }(B)\end{array}$ & $\begin{array}{l}-.081 \\
(.095)\end{array}$ & $\begin{array}{l}-.034 \\
(.040)\end{array}$ & $\begin{array}{l}.069 \\
(.081) \\
\end{array}$ & $\begin{array}{l}.018 \\
(.021)\end{array}$ & $\begin{array}{l}-.027 \\
(.030)\end{array}$ & $\begin{array}{l}.007 \\
(.039) \\
\end{array}$ & $\begin{array}{l}.004 \\
(.025) \\
\end{array}$ & $\begin{array}{l}.013 \\
(.032)\end{array}$ \\
\hline $\begin{array}{l}\text { Number of members } \\
15-18 \text { age group }\end{array}$ & $\begin{array}{l}-.099 \\
(.063) \\
\end{array}$ & $\begin{array}{l}-.042 \\
(.027) \\
\end{array}$ & $\begin{array}{l}.157^{* * *} \\
(.060)\end{array}$ & $\begin{array}{l}.041^{* * *} \\
(.015)\end{array}$ & $\begin{array}{l}-.030 \\
(.021)\end{array}$ & $\begin{array}{l}-.052^{* *} \\
(.026)\end{array}$ & $\begin{array}{l}.024 \\
(.017) \\
\end{array}$ & $\begin{array}{l}.050^{* *} \\
(.022)\end{array}$ \\
\hline $\begin{array}{l}\text { Share of main labor force }(A+B) \text { : } \\
\text { males with primary education }\end{array}$ & $\begin{array}{l}-.175 \\
(.223) \\
\end{array}$ & $\begin{array}{l}-.074 \\
(.094) \\
\end{array}$ & $\begin{array}{l}.112 \\
(.228) \\
\end{array}$ & $\begin{array}{c}.029 \\
(.059) \\
\end{array}$ & $\begin{array}{l}-.065 \\
(.072) \\
\end{array}$ & $\begin{array}{l}-.007 \\
(.092)\end{array}$ & $\begin{array}{l}.042 \\
(.060) \\
\end{array}$ & $\begin{array}{l}.080 \\
(.077) \\
\end{array}$ \\
\hline $\begin{array}{l}\text { Share of main labor force }(A+B) \text { : } \\
\text { females with primary education }\end{array}$ & $\begin{array}{l}-.291 \\
(.253)\end{array}$ & $\begin{array}{l}-.122 \\
(.107)\end{array}$ & $\begin{array}{l}.577^{* *} \\
(.251)\end{array}$ & $\begin{array}{l}.150^{* *} \\
(.065)\end{array}$ & $\begin{array}{l}-.099 \\
(.080)\end{array}$ & $\begin{array}{l}-.128 \\
(.104)\end{array}$ & $\begin{array}{l}.158^{* *} \\
(.067)\end{array}$ & $\begin{array}{l}.177^{\star *} \\
(.087)\end{array}$ \\
\hline $\begin{array}{l}\text { Share of main labor force }(A+B) \text { : } \\
\text { males with secondary education }\end{array}$ & $\begin{array}{l}-.374 \\
(.241) \\
\end{array}$ & $\begin{array}{l}-.158 \\
(.101) \\
\end{array}$ & $\begin{array}{l}.471^{* *} \\
(.238) \\
\end{array}$ & $\begin{array}{l}.122^{* *} \\
(.062)\end{array}$ & $\begin{array}{l}-.133^{*} \\
(.079)\end{array}$ & $\begin{array}{l}-.170^{*} \\
(.101)\end{array}$ & $\begin{array}{l}.100 \\
(.066) \\
\end{array}$ & $\begin{array}{l}.175^{* *} \\
(.085)\end{array}$ \\
\hline $\begin{array}{l}\text { Share of main labor force }(A+B) \text { : } \\
\text { females with secondary education }\end{array}$ & $\begin{array}{l}-.239 \\
(.260) \\
\end{array}$ & $\begin{array}{l}-.101 \\
(.110) \\
\end{array}$ & $\begin{array}{l}.394 \\
(.251) \\
\end{array}$ & $\begin{array}{c}.102 \\
(.065) \\
\end{array}$ & $\begin{array}{l}-.134 \\
(.085)\end{array}$ & $\begin{array}{l}-.120 \\
(.108)\end{array}$ & $\begin{array}{l}.103 \\
(.070) \\
\end{array}$ & $\begin{array}{l}.086 \\
(.090) \\
\end{array}$ \\
\hline $\begin{array}{l}\text { Share of main labor force }(A+B) \text { : } \\
\text { males with tertiary education }\end{array}$ & $\begin{array}{l}-.892^{* * *} \\
(.267) \\
\end{array}$ & $\begin{array}{l}-.376^{* * *} \\
(.112) \\
\end{array}$ & $\begin{array}{l}1.067^{\star \star *} \\
(.257)\end{array}$ & $\begin{array}{l}.277^{\star * *} \\
(.066)\end{array}$ & $\begin{array}{l}-.296^{* * *} \\
(.085) \\
\end{array}$ & $\begin{array}{l}-.232^{* *} \\
(.114) \\
\end{array}$ & $\begin{array}{l}.248^{* * *} \\
(.071)\end{array}$ & $\begin{array}{l}.224^{* *} \\
(.095) \\
\end{array}$ \\
\hline $\begin{array}{l}\text { Share of main labor force }(A+B) \text { : } \\
\text { females with tertiary education }\end{array}$ & $\begin{array}{c}-1.145^{* \star *} \\
(.335) \\
\end{array}$ & $\begin{array}{l}-.483^{* * *} \\
(.140) \\
\end{array}$ & $\begin{array}{l}1.446^{* * *} \\
(.299)\end{array}$ & $\begin{array}{l}.376^{* * *} \\
(.078)\end{array}$ & $\begin{array}{l}-.355^{* \star *} \\
(.106)\end{array}$ & $\begin{array}{l}-.305^{* *} \\
(.142)\end{array}$ & $\begin{array}{l}.486^{* * *} \\
(.088)\end{array}$ & $\begin{array}{l}.553^{* * *} \\
(.118)\end{array}$ \\
\hline \multicolumn{9}{|l|}{ Household non-labor capitals } \\
\hline Farm size (hectare) & $\begin{array}{l}1.263^{* * *} \\
(.109)\end{array}$ & $\begin{array}{l}.532^{* * *} \\
(.046)\end{array}$ & $\begin{array}{l}-.532^{* * *} \\
(.098) \\
\end{array}$ & $\begin{array}{l}-.138^{\star \star \star} \\
(.025) \\
\end{array}$ & $\begin{array}{l}.409^{* * *} \\
(.030)\end{array}$ & $\begin{array}{l}.153^{* * *} \\
(.049)\end{array}$ & $\begin{array}{l}-.130^{\star \star *} \\
(.025) \\
\end{array}$ & $\begin{aligned}-.079 * \\
(.041)\end{aligned}$ \\
\hline Farm size squared & $\begin{array}{l}-.165^{* * *} \\
(.019)\end{array}$ & $\begin{array}{l}-.070^{* * *} \\
(.008)\end{array}$ & $\begin{array}{l}.062^{* * *} \\
(.019) \\
\end{array}$ & $\begin{array}{l}.016^{* * *} \\
(.005)\end{array}$ & $\begin{array}{l}-.054^{* * *} \\
(.006)\end{array}$ & $\begin{array}{l}-.020^{* * *} \\
(.008)\end{array}$ & $\begin{array}{l}.016^{* * *} \\
(.005)\end{array}$ & $\begin{array}{l}.009 \\
(.006) \\
\end{array}$ \\
\hline $\begin{array}{l}\text { Value of houses and real estate } \\
\text { (million VND) }\end{array}$ & $\begin{array}{l}-.001^{*} \\
(.000)\end{array}$ & $\begin{array}{l}-.000^{*} \\
(.000)\end{array}$ & $\begin{array}{c}.000 \\
(.000) \\
\end{array}$ & $\begin{array}{c}.000 \\
(.000) \\
\end{array}$ & $\begin{array}{l}-.000 \\
(.000)\end{array}$ & $\begin{array}{l}-.000 \\
(.000) \\
\end{array}$ & $\begin{array}{c}.000 \\
(.000)\end{array}$ & $\begin{array}{l}-.000 \\
(.000)\end{array}$ \\
\hline \multicolumn{9}{|l|}{ Communal/provincial level variables } \\
\hline Access to paved roads $=1$ & $\begin{array}{l}-.102 \\
(.075)\end{array}$ & $\begin{array}{l}-.043 \\
(.032)\end{array}$ & $\begin{array}{c}.059 \\
(.069)\end{array}$ & $\begin{array}{c}.015 \\
(.018)\end{array}$ & $\begin{array}{l}-.018 \\
(.025)\end{array}$ & $\begin{array}{l}-.001 \\
(.031)\end{array}$ & $\begin{array}{c}.006 \\
(.021)\end{array}$ & $\begin{array}{c}.007 \\
(.026)\end{array}$ \\
\hline Own irrigation system = 1 & $\begin{array}{l}.044 \\
(.100)\end{array}$ & $\begin{array}{l}.019 \\
(.042)\end{array}$ & $\begin{array}{l}-.097 \\
(.100)\end{array}$ & $\begin{array}{l}-.025 \\
(.027)\end{array}$ & $\begin{array}{l}.026 \\
(.033)\end{array}$ & $\begin{array}{l}.000 \\
(.000)\end{array}$ & $\begin{array}{l}-.012 \\
(.029)\end{array}$ & $\begin{array}{l}.000 \\
(.000)\end{array}$ \\
\hline
\end{tabular}




\begin{tabular}{|c|c|c|c|c|c|c|c|c|}
\hline Number of natural disasters & $\begin{array}{l}-.071 \\
(.046)\end{array}$ & $\begin{array}{l}-.030 \\
(.019) \\
\end{array}$ & $\begin{array}{c}.024 \\
(.045)\end{array}$ & $\begin{array}{c}.006 \\
(.012)\end{array}$ & $\begin{array}{l}-.022 \\
(.015)\end{array}$ & $\begin{array}{c}.000 \\
(.000)\end{array}$ & $\begin{array}{c}.007 \\
(.013)\end{array}$ & $\begin{array}{c}.000 \\
(.000)\end{array}$ \\
\hline Price of paddy (thousand VND/kg) & $\begin{array}{l}.144 \\
(.224)\end{array}$ & $\begin{array}{l}.061 \\
(.095)\end{array}$ & $\begin{array}{l}-.084 \\
(.214)\end{array}$ & $\begin{array}{l}-.022 \\
(.056)\end{array}$ & $\begin{array}{l}.102 \\
(.075)\end{array}$ & $\begin{array}{l}.067 \\
(.117)\end{array}$ & $\begin{array}{l}-.041 \\
(.063)\end{array}$ & $\begin{array}{l}-.041 \\
(.097)\end{array}$ \\
\hline \multicolumn{9}{|l|}{ Time dummy variables } \\
\hline $\mathrm{T} 1=2004$ & $\begin{array}{c}.056 \\
(.072)\end{array}$ & $\begin{array}{c}.024 \\
(.031)\end{array}$ & $\begin{array}{l}.142^{* *} \\
(.066)\end{array}$ & $\begin{array}{l}.038^{* *} \\
(.018)\end{array}$ & $\begin{array}{c}.021 \\
(.024)\end{array}$ & $\begin{array}{c}.012 \\
(.027)\end{array}$ & $\begin{array}{l}.042^{* *} \\
(.020)\end{array}$ & $\begin{array}{l}.045^{* *} \\
(.022)\end{array}$ \\
\hline T2 = 2006 & $\begin{array}{l}.015 \\
(.089)\end{array}$ & $\begin{array}{c}.006 \\
(.037)\end{array}$ & $\begin{array}{l}.210^{* *} \\
(.083)\end{array}$ & $\begin{array}{l}.057^{* *} \\
(.024)\end{array}$ & $\begin{array}{l}-.021 \\
(.029)\end{array}$ & $\begin{array}{l}-.019 \\
(.037)\end{array}$ & $\begin{array}{l}.065^{* * *} \\
(.024)\end{array}$ & $\begin{array}{l}.071^{* *} \\
(.031)\end{array}$ \\
\hline Constant & $\begin{array}{l}.910^{*} \\
(.528)\end{array}$ & & $\begin{array}{c}-1.149^{* *} \\
(.511)\end{array}$ & & $\begin{array}{l}.529^{* * *} \\
(.173)\end{array}$ & $\begin{array}{l}.681^{* \star * *} \\
(.248)\end{array}$ & $\begin{array}{l}.083 \\
(.145)\end{array}$ & $\begin{array}{l}-.018 \\
(.207)\end{array}$ \\
\hline Number of groups & \multicolumn{2}{|c|}{305} & \multicolumn{2}{|c|}{305} & 305 & 305 & 305 & 305 \\
\hline Number of observations & \multicolumn{2}{|c|}{915} & \multicolumn{2}{|c|}{915} & 915 & 915 & 915 & 915 \\
\hline - Left-censored (at zero) & \multicolumn{2}{|c|}{287} & \multicolumn{2}{|c|}{621} & & & & \\
\hline - Uncensored & \multicolumn{2}{|c|}{283} & \multicolumn{2}{|c|}{252} & & & & \\
\hline - Right-censored (at one) & \multicolumn{2}{|c|}{345} & \multicolumn{2}{|c|}{42} & & & & \\
\hline Wald chi2(22) & \multicolumn{2}{|c|}{180.73} & \multicolumn{2}{|c|}{107.91} & & & & \\
\hline Prob > chi2 & \multicolumn{2}{|c|}{0.0000} & \multicolumn{2}{|c|}{0.0000} & & & & \\
\hline Log likelihood & \multicolumn{2}{|c|}{-713.2647} & \multicolumn{2}{|c|}{-549.0334} & & & & \\
\hline $\operatorname{Pr}\left(0<S^{*}<1\right)$ & \multicolumn{2}{|c|}{0.4217} & \multicolumn{2}{|c|}{0.2599} & & & & \\
\hline Wald chi2 & & & & & 291.08 & & 128.73 & \\
\hline Prob>chi2 & & & & & .0000 & & .0000 & \\
\hline $\mathrm{F}$ & & & & & & 2.47 & & 3.88 \\
\hline Prob $>F$ & & & & & & 0.0005 & & 0.0000 \\
\hline R-squared & & & & & .3840 & .0741 & .1487 & .1117 \\
\hline Hausman test-chi2 & & & & & \multicolumn{2}{|c|}{75.81} & \multicolumn{2}{|c|}{9.68} \\
\hline Prob>chi2 & & & & & \multicolumn{2}{|c|}{0.0000} & \multicolumn{2}{|c|}{0.9605} \\
\hline
\end{tabular}

Note: ${ }^{*},{ }^{* *},{ }^{* *}$ respectively denote statistically significant at, at least the 10,5 , and 1 percent level.

The OLS-FE estimates show that the temporal income diversification, especially movement into non-farm wage employment, is strongly influenced by the quality of a household's main labor force. The estimates indicate that a 10-percentage point increase in the proportion of females (males) with tertiary education increases the share of time allocated to non-farming activities by more than 5 (2) percentage points while at the same time reducing farming activities by more than 3 (2) percentage points. Since this specification controls for unobserved attributes that do not change over time, the estimates support the idea that households with younger and more educated workers are driving the movement towards non-farming activities. The increasing supply of such workers interacting with increased job opportunities in this sector which in turn was likely to have been driven by various policy changes that supported the set up of such enterprises, seem to be the driving forces that move households away from agricultural related activities.

As has been seen over the various years, farm size continues to play a role in motivating time-allocation towards farming activities. The various meso-level variables such as price of paddy, number of natural disasters and access to infrastructure, which capture the incentives to diversify appear to have limited effects on driving time-allocation patterns. It is likely that the incentive to diversify effect is captured by time dummies, which indicate that over time in both 2004 and 2006 there is an increasing tendency to spend more time on non-farming activities. The year dummies reveal that in 2004, as compared to 2002, households spend an additional 4.5 percentage points of their time on nonfarming wage employment while in 2006 this increases to 7.1 as compared to 2002. These estimates suggest that regardless of a household's labor, land and financial 
endowments, secular factors that influence all households (such as increasing labor market opportunities, changes in policy environment that make non-farming activities more attractive) are moving them towards non-farming activities.

\section{Conclusions}

This paper used panel data covering a 13-year span to examine the factors that drive time-allocation patterns in rural parts of the MRD. The analysis was based on a framework that conceptualized diversification as a function of a household's capacity to diversify and incentives (both push and pull factors) to diversify.

The main points emerging from the analysis is that income diversification is strongly influenced by household labor capacity. Both household labor quality and quantity play a substantial role in channeling households to non-farming wage activities. The estimates suggest that the relationship between household labor capacity and increasing insertion in non-farming wage activities is not driven by unobserved timeinvariant factors such as household ability and motivation, but is indeed driven by the higher labor capacity of households.

The steady increase in the importance of these capacity variables in driving time-allocation patterns despite the increase in the supply of educated labor suggests that over the period under scrutiny, labor demanded, across all education levels, by non-farming enterprises outstrips labor supply. In terms of the other household capacity variables, the effect of farm size is much larger in terms of retaining households in traditional occupations as compared to pushing them towards non-farm wage employment. Other variables such as household access to financial capital do not play an important role.

While specific variables that were expected to capture the incentives to diversity such as rice prices, rural infrastructure, the risk of natural disasters do not seem to exert an effect on time-allocation patterns, the estimates shows that over time, regardless of household labor, land or financial capacity there is a secular tendency to move towards non-farming wage activities. This movement is probably driven by policy changes, in particular the enterprise law, which have led to the creation of a more conducive environment for setting up non-farming enterprises, which affect all households equally.

\section{References}

Abdulai, A., \& CroleRees, A. (2001). Determinants of Income Diversification amongst Rural Households in Southern Mali. Food Policy, 26(4), 437-452.

Abdulai, A., \& Delgado, C. L. (1999). Determinants of Nonfarm Earnings of Farm-Based Husbands and Wives in Northern Ghana. American Journal of Agricultural Economics, 81(1), 117-130.
Alderman, H., Paxson, C. H., \& DEC (1992). Do the poor insure? A synthesis of the literature on risk and consumption in developing countries (English) (Policy, Research working papers no. WPS 1008). Washington DC: World Bank. Retrieved February 28, 2020, from http://documents.worldbank.org/curated/ en/682441468765261969/Do-the-poor-insure-A-synthesis-ofthe-literature-on-risk-and-consumption-in-developing-countries.

Barrett, C. B., \& Reardon, T. (2000). Asset, Activity, and Income Diversification Among African Agriculturalists: Some Practical Issues (Working Papers 14734). New York, NY: Cornell University, Department of Applied Economics and Management. Retrieved February 28, 2020, from http://barrett. dyson.cornell.edu/files/papers/BASIS1.pdf.

Barrett, C. B., Reardon, T., \& Webb, P. (2001). Nonfarm Income Diversification and Household Livelihood Strategies in Rural Africa: Concepts, Dynamics, and Policy Implications. Food Policy, 26(4), 315-331.

Carney, D., Drinkwater, M., Rusinow, T., Neefjes, K., Wanmali, S., \& Singh, N. (1999). Livelihoods Approaches Compared: A brief comparison of the livelihoods approaches of the UK Department for International Development (DFID), CARE, Oxfam and the United Nations Development Programme (UNDP). London, England: Department for International Development.

Chulanova, Z. K., \& Ussenova, A. S. (2015). Human Capital and Methodic of Determination of Its Cost: A Case of Kazakhstan. Journal of Asian Finance, Economics and Business, 2(2), 19-25. https://doi.org/10.13106/jafeb.2015.vol2.no2.19.

Corral, L., \& Reardon, T. (2001). Rural Nonfarm Incomes in Nicaragua. World Development, 29(3): 427-442.

Davis, J. R. (2004). The Rural Non-Farm Economy, Livelihoods and their Diversification: Issues and Options. Chatham, UK: Natural Resources Institute.

Davis, J. R., \& Bezemer, D. (2003). Key Emerging and Conceptual Issues in the Development of the RNFE in Developing Countries and Transition Economies (NRI Report to Department for International Development and World Bank No. 2753). Washington D.C.: World Bank. Retrieved February 25, 2020, from http://www.projects.nri.org/rnfe/pub/papers/2755.pdf.

Ellis, F. (1993). Peasant economics: Farm households and Agrarian development. Cambridge, MA: Cambridge University Press.

Ellis, F. (1998). Household Strategies and Rural Livelihood Diversification. Journal of Development Studies, 35(1), 1-38.

Ellis, F. (2000). Rural Livelihoods and Diversity in Developing Countries. New York, NY: Oxford University Press.

Escobal, J. (2001). The Determinants of Non-farm Income Diversification in Rural Peru. World Development, 29(3), 497-508.

Greene, W.H. (2003). Econometric Analysis (5th ed.). Upper Saddle River, NJ: Prentice Hall.

GSO (2002). Khao Sat Muc Song Ho Gia Dinh 2002 (Vietnam Household Living Standards Survey 2002). Hanoi, Vietnam: General Statistics Office. 
GSO (2004). Khao Sat Muc Song Ho Gia Dinh 2004 (Vietnam Household Living Standards Survey 2004). Hanoi, Vietnam: General Statistics Office.

GSO (2006). Khao Sat Muc Song Ho Gia Dinh 2006 (Vietnam Household Living Standards Survey 2006). Hanoi, Vietnam: General Statistics Office.

Haggblade, S., Hazell, P., \& Reardon, T. (2002). Strategies for Stimulating Poverty-Alleviating Growth in the Rural Nonfarm Economy in developing Countries (EPTD Discussion Paper no. 92). Washington D.C.: World Bank. Retrieved February 28, 2020, from https://www.researchgate.net/ publication/5056182_Strategies_for_Stimulating_PovertyAlleviating_Growth_in_the_Rural_Nonfarm_Economy_in Developing_Countries.

Hossain, M. (2004). Rural non-farm economy in Bangladesh: evidence from household surveys. Economic and Political Weekly, 34(36), 4053-4058.

Lanjouw, P., \& Feder, G. (2001). Rural Non-farm Activities and Rural Development: From Experience Towards Strategy (The World Bank Rural Development Strategy Background Paper no. 4). Washington D.C.: World Bank. Retrieved February 28, 2020, from http://documents.worldbank.org/curated/ pt/903001468740446659/Rural-non-farm-activities-and-ruraldevelopment-from-experience-towards-strategy.

Lanjouw, P., \& Shariff, A. (2002). Rural Non-Farm Employment in India: Access, Income and Poverty Impact (Working Paper Series No. 81). New Delhi, India: National Council of Applied Economic Research. Retrieved February 28, 2020, from www. ncaer.org/free-download.php?pID=77.

McDonald, J. F., \& Mofitt, R. A. (1980). The uses of Tobit analysis. The Review of Economics and Statistics, 62(2), 318-321.

Minot, N., Epprecht, M., Anh, T. T. T., \& Trung, L. Q. (2006). Income Diversification and Poverty in the Northern Uplands of Vietnam (Research Report no.145). Washington DC.: International Food Policy Research Institute. Retrieved February 22, 2020, from http://ebrary.ifpri.org/cdm/ref/ collection/p15738coll2/id/125250/.

Ramcharran, H. (2017). The impact of workers' remittances on household consumption in India: Testing for consumption Augmentation and stability. Journal of Asian Finance, Economics and Business, 4(4), 51-60. http://dx.doi. org/10.13106/jafeb.2017.vol4.no4.51

Reardon, T. (1997). Using Evidence of Household Income Diversification to Inform Study of the Rural Nonfarm Labor Market in Africa. World Development, 25(5), 735-747.

Reardon, T., Berdegué, J., Barrett, C. B., \& Stamoulis, K. (2007). Household Income Diversification into Rural Nonfarm Activities. In S. Haggblade, P. B. R. Hazell, \& T. Reardon (Eds), Transforming the Rural Nonfarm Economy: Opportunities and Threats in the Developing World (pp. 115-140). Baltimore, MD: Jonhs Hopkins University Press.

Senadjki, A., Mohd, S., Bahari, Z., \& Hamad, A. F. C. (2017). Assets, Risks and Vulnerability to Poverty Traps: A Study of Northern
Region of Malaysia. Journal of Asian Finance, Economics and Business, 4(4), 5-15. http://dx.doi.org/10.13106/jafeb.2017. vol4.no4.5

Start, D. (2001). Rural diversification: What hope for the poor? (ODI Working). London, England: Overseas Development Institute. Retrieved February 22, 2020, from https://www. odi.org/sites/odi.org.uk/files/odi-assets/publications-opinionfiles/5900.pdf.

van de Walle, D. P., \& Cratty, D. (2004). Is the Emerging Non-farm Market Economy the Route Out of Poverty in Vietnam? The Economics of Transition, 12(2), 237-274.

World Bank (1995). Viet Nam Living Standards Survey, 1992 1993. Washington D.C.: The World Bank. Retrieved February 22, 2020, from https://datacatalog.worldbank.org/dataset/ vietnam-living-standards-survey-1992-1993.

World Bank (2001). Viet Nam Living Standards Survey (VLSS), 1997-98: Basic Information. Washington D.C.: World Bank. Retrieved February 22, 2020, from http://siteresources.worldbank.org/INTLSMS/Resources/3358986-1181743055198/3877319-1181827303756/vn98bifBasicInformation.pdf.

\section{Endnotes}

${ }^{1}$ Criterion for education classification is the number of years individuals have spent in school. Accordingly, the primary, secondary and higher education level are ascribed to individuals who have spent 1-5, 6-10 and more than 10 years of schooling, respectively.

${ }^{2}$ The proportion of household main labour force accounted for both males and females that have no education level attainment (zero-year of schooling) does not appear to change over time (8 percent in 2002 and 7 percent in both years 2004 and 2006).

${ }^{3}$ While current migrants are included as household members, permanent migrants are not considered household members. Over time there is a sharp drop in the number of current migrants. The reasons for this are not entirely clear. It may well be that better access to non-farm jobs worked towards reducing temporary migration. Furthermore, while it is possible that being a current migrant and working in non-farm wage employment are simultaneously determined there is by no means a one-for-one relationship between the two as current migrants are engaged in a range of farming and non-farming activities.

${ }^{4}$ In 1993 and 1998, natural disasters are defined as the number of major disasters during the last 5 years preceding the survey while in 2004 and 2006 the time horizon is the last 3 years preceding the survey. Major disasters are droughts, typhoons, cyclones, and serious diseases.

${ }^{5}$ Due to the high correlation with farm size (87 percent) the amount of land with land-use rights certificate is not included in the specifications. Similarly, since information on the number of current migrants is not available for 2002 it is not included. 
